\title{
EFFECT OF DIETARY GRAPE SEED SUPPLEMENTATION AS A NATURAL GROWTH PROMOTER ON THE GROWTH PERFORMANCE OF JAPANESE QUAIL
}

\author{
A.A. Abdel-Wahab ${ }^{1}$, I.A. Abdel-Kader ${ }^{1}$ and Enas M. Ahmad ${ }^{2}$ \\ ${ }^{1}$ Poult. Prod. Dep., Fac. of Agric., Fayoum Uni., 63514 Fayoum, Egypt. \\ ${ }^{2}$ Anim and Poult. Prod. Dep., Fac. of Agric. and Nat. l Reso., Aswan Uni., 81528 Aswan, Egypt
}

(Received 3/7/2018, accepted 15/8 /2018)

\section{SUMMARY}

$\mathrm{T}$ his study aimed to describe and reveal the health promoting activities associated with polyphenol in grape seeds (GS) supplemented to grower diets of Japanese quail. A total of 270, one day-old quail were distributed at equal body weights into three groups: 1- as a control group (with no additives), 2control diet $+1 \%$ GS (powder), and 3- control diet $+3 \%$ GS to examine the effect of GS supplementation on the growth performance, carcass characteristics, serum biochemical indices, antioxidants status, immune response and intestinal microflora in Japanese quail. The most important results revealed that, inclusion of GS in quail diets improved growth performance tested at 38 days and during the period from 10 to 38 days of age, desirably decreased total cholesterol lipid profile, random blood sugar and liver enzyme activities, increased glutathione peroxidase, immune responses (IgG, $\operatorname{IgA}$ and $\operatorname{IgM})$ and decreased thiobarbituric acid- reactive substances as compared with the control group, increased Lactobacillus spp as compared with the control group and decreased the number of both E-coli and Salmonella as compared with the control. Therefore, GS up to $3 \%$ can be used as a growth promoter without impairing quail growth.

Keywords: Polyphenol, grape seeds, growth promoter, performance, biochemical indices, antioxidant status, intestinal microflora, quail.

\section{INTRODUCTION}

In Egypt, grapes are the second most popular and important fruit crop planted after citrus, but their seeds neglected to eat what is perhaps their healthiest feature. There are 74873 ha planted with grapes that annually produce 1716846 tones (FAOSTAT, 2018). Grapes in Egypt belong to two species (Vitis vinifera L.; Bayer Crop Science Egypt, 2012). Searching for new efficient natural antioxidants particularly is a crucial task for nutritionists to satisfy the concerns of a consumer safety. Grape seeds (GS) as a by-products of wine/grape juice industries are rich in antioxidant compounds, including phenolic compounds (predominantly tannins), and considered an abundant source of flavonoids and has a high concentration of vitamin E, linoleic acid and oligomeric proanthocyanidins (OPCs) which are well known for their antioxidant activity and have been shown to reduce the risk of oxidative stress against free radical-mediated damage (Gorinstein et al., 1994). Grape seeds as plant-derived antioxidants can greatly reduce damage due to oxidants by neutralizing free radicals before they can attack the cells and thereby prevent damage to lipids, proteins, enzymes, carbohydrates and DNA (Satyam et al., 2013). Polyphenols accumulate as 60-70\% in the solid parts of the GS (Bişboacă, 2012)_and might act as potent inhibitors of glucose absorption and OPCs not only have antioxidant activity but are also antibacterial (Furiga et al., 2008 and Perumalla and Hettiarachchy, 2011), antiviral, anti-carcinogenic, antiinflammatory, anti-allergic and vasodilator actions according to the Journal Alternative Medicine Review. Oligomeric proanthocyanidins may be a useful component in the treatment of a number of conditions because their role as inhibiter of lipid peroxidation, platelet aggregation, capillary permeability and fragility, and to affect enzyme systems. Therefore, the more research that emerges on 
GS, the more it becomes clear they have wide-reaching health benefits. Grape seeds powder is considered to be a better source of antioxidative constituents because the antioxidant potential of grape polyphenols (GPP) is 20 times higher than that of vitamin $\mathrm{E}$ and 50 times higher than that of vitamin $\mathrm{C}$ (Carpenter et al., 2007) which successfully helped to protect against diseases caused by many pathogen (Tepe et al., 2004 and Fawzia et al., 2014). Earlier, degenerative changes in liver and intestine of poultry on feeding of high polyphenols diets had been reported. So, GPP by-products could be used as a feed supplement to improve antioxidant status and immunity of birds, whereas the physiological effects of these molecules are not completely known. Dietary supplementation of GS powder at $0.5 \%, 1 \%$ and $1.5 \%$ levels resulted in improving growth performance and increasing the resistance of rabbits to oxidative stress during hot weather (Fawzia et al., 2014). Iqbal et al. (2015) reported that increasing GPP level in place of vitamin E, the thiobarbituric acid reactive substances decreased. Lichovnikova et al. (2015) found that red GS powder had a positive effect on the content of Lactobacillus spp in the lower part of the ileum, however, the red GS powder at a concentration of $15 \mathrm{~g} / \mathrm{kg}$ in the grower diet did not affect the growth of broilers, and it is suitable for broiler diets to improve the functionality of gastrointestinal tract. However, Abu Hafsa and Ibrahim (2017) reported that both of final body weight and body weight gain was increased by addition of $20 \mathrm{~g} / \mathrm{kg}$ GS to the basal diet with improving in feed conversion ratio but, feed intake not affected, while carcass physical and chemical composition characteristics of meat influenced by treatments as dietary $20 \mathrm{~g}$ GS significantly increased carcass yield, dressing and gizzard\%, the addition of $40 \mathrm{~g} / \mathrm{kg}$ of GS significantly reduced abdominal fat $\%$ in the birds. Also, Pascariu et al. (2017) reported that the dose of $5 \mathrm{~g} / \mathrm{kg} \mathrm{GS}$ in the diet increased growing rate and feed efficiency. Brenes et al. (2016) illustrated the benefits of GS as a functional feed additive in monogastric nutrition resulting in inhibition of lipid peroxidation in meat. The addition of $40 \mathrm{~g}$ of GS significantly increased the activity of reduced glutathione, catalase, superoxide dismutase, glutathione peroxidase and GST, and decreased thiobarbituric acid- reactive sub-stances levels compared with the control group (Abu Hafsa and Ibrahim, 2017), moreover, plasma protein, albumin, globulin, aspartate aminotransferase and alanine aminotransferase concentrations did not differ in GS groups than the control group. Broilers fed diets supplemented with GS had lower ileal E-coli but higher Lactobacillus spp (Abu Hafsa and Ibrahim, 2017). Also, Brenes et al. (2016) showed that the GS proved to be effective in modifying the intestinal microflora. They indicated that GS could be recommended as an herbal supplement in the diet chickens to improve broiler performance, reduce blood lipids, enhance antioxidant capacity and decrease detrimental bacteria in the ileum. Since, adequate evidence found to support the efficiency of the antimicrobial activity of polyphenols. However, researches on the possible stimulatory role of phenolic compounds on performance, serum lipid profile, antioxidants status and intestinal microflora in quail is limited and little studies related to the effects of GPP in birds have been published (Viveros et al., 2011).

Therefore, this study aimed to describe and reveal other valuable health promoting activities furthermore to its radical scavenging capacity associated with polyphenol in GS supplemented to grower diets of Japanese quail to fill this gap in this aspect.

\section{MATERIALS AND METHODS}

Grape seed collection: GS (Vitis vinifera) were obtained from El-Ahram Heineken for beverages (Gianaclis Company) in the Gianaclis region, Abu Elmatamir, Beheira Governorate, Egypt. The seeds were washed with tap water and air-dried. The total values of phenolic compounds, flavonoids and tannin contents were measured colorimetrically, using Folin-Ciocalteu method according to Rebaya et al. (2015), total phenolic contents (mg GAE/g DW) 49.54, flavonoid contents (mg RE/g DW) 23.20 tannin contents (mg CE/g DW) 3.85. The proximate composition of GS was measured by AOAC procedures (AOAC, 2005) to be dry matter $(90.5 \%)$, ash $(4.3 \%)$, crude protein $(8.11 \%)$, fat $(11.5 \%)$ and organic matter $(95.7 \%)$.

\section{Experimental birds design and diets:}

A total of 270, one day- old quail were obtained from market and initially fed a control diet for 10 days. Quails were randomly distributed at equal body weights into three groups: 1-as a control group (with no additives), 2 -control diet $+1 \%$ grape seed (powder) and 3 -control diet $+3 \%$ grape seed. Each group contained three replicates of 30 birds each. Birds were raised in electrically heated batteries with 
raised wire mesh floors and had free access to feed and water. Batteries were placed into a room provided with continuous lighting and fans for ventilation. The birds were reared under similar environmental conditions and were given the experimental diets from the end of the first 10 days of age until 38 days of age (growing period). The control diet was formulated to meet the nutrient requirements of the quails during the experiment period from 0 to 38 days (NRC, 1994).

The composition of the basal diet is presented in Table 1. Chicks were exposed to continuous lighting and feed and water were supplied ad libitum ad libitum. At 31 day of age, birds were vaccinated against Newcastle virus (Lasota) via spraying.

Table (1): Feed ingredients and chemical composition of basal experimental diet.

\begin{tabular}{|c|c|}
\hline Feed Ingredient & Basal diet $\%$ \\
\hline Yellow corn & 56.00 \\
\hline Soybean meal (44 CP \%) & 32.00 \\
\hline Concentrate meal ${ }^{1}(50 \mathrm{CP} \%)$ & 10.30 \\
\hline Dicalcuom phosphate $^{2}$ & 0.50 \\
\hline DL-methionine & 0.10 \\
\hline Sodium chloride & 0.30 \\
\hline Vegetable oil & 0.50 \\
\hline Vitamin and mineral premix ${ }^{3}$ & 0.30 \\
\hline \multicolumn{2}{|l|}{ Calculated analysis: } \\
\hline Metabolizable energy (Kcal/Kg & 2919 \\
\hline Crude protein (CP) & 24.00 \\
\hline Crude fiber (CF) & 3.61 \\
\hline Calcium $(\mathrm{Ca})$ & 0.8 \\
\hline Available phosphorus & 0.54 \\
\hline Lysine & 1.62 \\
\hline Methionine & 0.603 \\
\hline Methionine+Cystine & 0.89 \\
\hline \multicolumn{2}{|c|}{ '- Concentrate meal\%: CP 50, CF 1.3, Ca 4.72, Av P 3.1, lysine 6, methionine 2 and $M E 2650 \mathrm{kcal} / \mathrm{kg}$. } \\
\hline \multicolumn{2}{|c|}{ 2- Dicalcuom phosphate Ca $28 \%$, total P $19 \%$} \\
\hline \multicolumn{2}{|c|}{$\begin{array}{l}{ }^{3} \text {-Premix provided per } \mathrm{kg} \text { of diet: vitamin } A, 12000 \mathrm{IU} \text {; vitamin } \mathrm{D} 3,2400 \mathrm{IU} \text {; vitamin } \mathrm{E}, 30 \mathrm{mg} \text {; vitamin } \mathrm{K}_{3}, 4 \mathrm{mg} \text {; } \\
\text { vitamin } B_{1}, 3 \mathrm{mg} \text {; vitamin } B_{2}, 7 \mathrm{mg} \text {; vitamin } B_{6}, 5 \mathrm{mg} \text {; vitamin } B_{12}, 15 \mu \mathrm{\mu g} \text {; niacin, } 25 \mathrm{mg}, \mathrm{Fe}, 80 \mathrm{mg} ; \text { folic acid, } 1 \mathrm{mg} \text {; } \\
\text { pantothenic acid, } 10 \mathrm{mg} ; \text { biotin, } 45 \mathrm{mg} \text {; choline, } 125,000 \mathrm{mg} ; \mathrm{Cu}, 5 \mathrm{mg} ; \mathrm{Mn}, 80 \mathrm{mg} ; \mathrm{Zn}, 60 \mathrm{mg} ; \mathrm{Se}, 150 \mu \mathrm{g} \text {. }\end{array}$} \\
\hline
\end{tabular}

\section{Growth performance and carcass traits measured:}

Live body weights of chicks (LBW) were individually weighed and feed consumptions per pen were weekly recorded (FI), the uneaten feed discarded, body weight gain (BWG) as a difference between final and initial body weights, growth rate (GR) (Brody, 1945), feed conversion ratio (FCR) and performance index (PI) were calculated according to (North, 1981). At the end of the experiment (38 days of age), six birds from each group were reweighed and slaughtered by cutting the Jugular vein, de feathered and eviscerated to determine some carcass traits, dressing \% and total giblets \%. Individual blood samples were collected for blood analysis.

\section{Blood biochemical, anti-oxidant and immunity:}

At slaughter, individual 18 blood samples were collected in dry clean centrifuge tubes and serum was separated through centrifugation at $3000 \mathrm{rpm}$ for 15 minutes and assigned for subsequent determination. Quantitative determination was done for the following: total cholesterol (Chol), high density lipoproteins (HDL), low density lipoproteins (LDL), very low-density lipoproteins (VLDL) triglycerides (Trig), Aspartate aminotransferase (AST) and Alanine aminotransferase (ALT). All blood biochemical parameters were calorimetrically determined using commercial diagnosing kits (produced by Spectrum Diagnostics Company, Egypt). The glutathione peroxidase (GPx, EC 1.11.1.9) determined calorimetrically according to Paglia and Valentine (1967) and thiobarbaturic acid- reactive substances' (TBARS) was performed according to Yagi (1998) using commercial diagnosing kits produced by 
Cayman Chemical Company (USA). The method used for the assay of chicken Immunoglobulins Isotypes IgG, IgM, and IgA in Sandwich ELISA described by Erhard et al. (1992) the absorbance measured on an ELISA plate reader set at $450 \mathrm{~nm}$.

\section{Microbial analysis:}

After slaughter, intestinal content was immediately collected in sterile glass containers, digesta was evacuated and mixed. At $4{ }^{\circ} \mathrm{C}$, the sealed containers were kept in the laboratory till enumeration of microbial population. Samples (1g of the mixed fresh mass) were taken into sterile test tubes, diluted 1:10 in sterile $0.1 \%$ peptone solution and homogenized for $3 \mathrm{~min}$ in a Stomacher homogenizer. Ten fold serial dilutions up to $10^{-7}$ of each sample were prepared in nine $\mathrm{ml}$ of $0.1 \%$ sterile peptone solution. Viable counts of Salmonella spp, Escherichia coli (E. coli) and Lactobacilli spp were performed. One milliliter of the serial dilution was incubated into sterile Petri dishes and sealed with an appropriate medium. Lactobacillus spp. colony count was determined using MRS agar (Biokar Diagnostic, France) after incubation in an anaerobic chamber at $37^{\circ} \mathrm{C}$ for $72 \mathrm{~h}$. Salmonella and E. coli colonies were counted on brilliant green agar plate and incubated at $37^{\circ} \mathrm{C}$ for $24 \mathrm{~h}$ ). After cultivation in Petri dishes, the total colony count for Lactobacilli, Salmonella and E. coli was then calculated as the number of colonies by reciprocal of the dilution. The microbial counts were determined as colony forming units (cfu) per gram of sample.

\section{Statistical analysis:}

Using General Linear Models (GLM) procedure of SPSS (2013), studied traits were subjected to a two-way analysis of variance with treatment and sex as main effects as follows: $Y_{i j k}=\mu+T_{i}+S_{j}+e_{i j k}$.

Where: $\mathrm{Y}_{\mathrm{ijk}}$ : Observed value in the $i^{\text {th }}$ treatment of the $\mathrm{j}^{\text {th }}$ sex of the $\mathrm{k}^{\text {th }}$ individual, $\mu$ : Overall mean, $\mathrm{T}_{\mathrm{i}}$ : Treatment effect (i: 1 to 3), $S_{j}$ : sex effect (j: 1 and 2) and $\mathrm{e}_{\mathrm{ijk}}$ : random error term. Means were compared for main effects by Duncan's new multiple range test (Duncan, 1955) when significant $F$ values were obtained.

\section{RESULTS AND DISCUSSION}

All growth traits tested at 38 days and during the period from 10 to 38 days of age were significantly $(P \leq 0.001)$ affected (Table 2$)$ by dietary treatment. Quail fed diets supplemented with GS showed better growth performance and superior LBW at 38 days, BWG, lower FI, better FC, faster GR and higher PI for both GS 3\% followed by GS 1\% than the control group during the period from 10 to 38 days of age. Females had heavier LBW at 38 days, BWG, better FC and higher PI than males during the period from 10 to 38 days of age due to significant $(P \leq 0.001)$ sex effect. The polyphenol content of dried GS powder in the present study was $49.54 \mathrm{~g} / \mathrm{kg}$ so $1 \%$ and $3 \%$ grape seed powder $/ \mathrm{kg}$ diet were equivalent to $0.49 \mathrm{~g}$ and $1.48 \mathrm{~g}$ polyphenols $/ \mathrm{kg}$ diet. Based on the results of the present study, quail diets containing $3 \% \mathrm{GS}$ $/ \mathrm{kg}$ diet were effective in enhancing growth performance better than $1 \% \mathrm{GS} / \mathrm{kg}$ diet. This result was inconsistent with the results observed by both Fawzia et al. (2014), who indicated that rabbits receiving $1.0 \%$ of GSP had a heavier final body weight and average daily weight gain than the other groups; however, the level of $1.5 \%$ GSP had less FI and showed the best value of feed conversion as compared to the other groups also, Pascariu et al. (2017) found that the lowest level of GSP $5 \mathrm{~g} / \mathrm{kg}$ diet showed better performance than $10 \mathrm{~g}$ and $20 \mathrm{~g} / \mathrm{kg}$ diet. The present results are in line with growth performance results shown by Abu Hafsa and Ibrahim (2017), who reported that 2\% GS were effective than 4\% in enhancing growth performance. These improvements in BWG and FCR were possibly due to the biological function of phenolic compounds in GSs as well as their natural antioxidant activity which can protect the intestinal mucosa against oxidative damage and pathogens and limit peristaltic activity in digestive disorders, thereby preventing diarrhea (Kermauner and Laurenčič, 2008). Furthermore, the effect of tannin in reducing intestinal movement might lead to better absorption of nutrients that enhanced BWG (Ismail et al., 2003)., Brenes et al. (2008) and Goñi et al. (2007) for broiler chickens and Fawzia et al. (2014) for growing rabbits. Conversely, Nardoia (2016) found that the inclusion of GS in chicken diets did not change growth performance. However, Hughes et al., (2005) found a growth depression with the use of GSE containing $90.2 \%$ of total phenolics, expressed as Gallic acid, and incorporated in the diet at $30 \mathrm{~g} / \mathrm{kg}$. 
Either treatment or sex effects had no significant influence $(\mathrm{P}>0.05)$ on all carcass traits studied, except edible parts weight with sex, where, sex was in favor of females which had significantly $(P \leq 0.02)$ higher value of edible parts weight than males (Table 3). These results are in agreement with the reports of Brenes et al. (2008) and Abu Hafsa and Ibrahim (2017) they reported that the inclusion of graded concentrations of GP did not affect all carcass traits, the relative abdominal fat, liver, pancreas, and spleen weight This was in partial in agreement with the results of Hajati et al. (2015) who found that dietary supplementation of GSE did not affect the percentage of edible carcass, liver, empty gizzard and abdominal fat of birds. Similarly, Fawzia et al. (2014) indicated that GSP supplementation in the diet did not significantly affect all of carcass traits studied, except for pre-slaughter and carcass weight percentages, which were significantly higher in rabbits receiving 1.0\% GSP. Recent results from Ebrahimzadeh et al. (2018) showed that GP supplementation had no significant effect on carcass, abdominal fat, liver or heart weights in birds.

Table (2): Effects of treatment and sex on growth traits of Japanese quail (Main effect).

\begin{tabular}{|c|c|c|c|c|c|c|c|}
\hline \multirow{2}{*}{ Item } & \multicolumn{2}{|c|}{ LBW, g (age, days) } & BWG (g) & FI (g) & $\mathrm{FC}(\mathrm{g} / \mathrm{g})$ & $\mathrm{GR}(\mathrm{g} / \mathrm{g})$ & PI \% \\
\hline & 10 & 38 & \multicolumn{5}{|c|}{ age period, days 10 to 38 days of age } \\
\hline \multicolumn{8}{|l|}{ Treatment effect: } \\
\hline Control & 40.68 & $201.09^{\mathrm{b}}$ & $160.41^{b}$ & $584.22^{\mathrm{a}}$ & $3.67^{\mathrm{a}}$ & $1.33^{\mathrm{b}}$ & $5.56^{\mathrm{b}}$ \\
\hline Grape seeds $1 \%$ & 41.24 & $225.94^{\mathrm{a}}$ & $184.70^{\mathrm{a}}$ & $518.15^{b}$ & $2.82^{\mathrm{b}}$ & $1.38^{\mathrm{a}}$ & $8.09^{\mathrm{a}}$ \\
\hline Grape seeds $3 \%$ & 41.36 & $225.29^{\mathrm{a}}$ & $183.93^{\mathrm{a}}$ & $511.06^{\mathrm{c}}$ & $2.79^{b}$ & $1.38^{\mathrm{a}}$ & $8.13^{a}$ \\
\hline $\mathrm{SEM}^{1}$ & 0.66 & 1.91 & 1.87 & 2.53 & 0.03 & 0.01 & 0.12 \\
\hline P-value & 0.77 & 0.001 & 0.001 & 0.001 & 0.001 & 0.001 & 0.001 \\
\hline \multicolumn{8}{|l|}{ Sex effect: } \\
\hline Females (F) & 41.45 & $221.89^{\mathrm{a}}$ & $180.44^{\mathrm{a}}$ & 538.37 & $3.03^{\mathrm{b}}$ & 1.37 & $7.58^{\mathrm{a}}$ \\
\hline Males (M) & 40.74 & $213.00^{\mathrm{b}}$ & $172.26^{\mathrm{b}}$ & 536.74 & $3.15^{\mathrm{a}}$ & 1.36 & $6.93^{b}$ \\
\hline SEM & 0.54 & 1.55 & 1.46 & 2.04 & 0.03 & 0.01 & 0.11 \\
\hline P-value & 0.36 & 0.001 & 0.001 & 0.47 & 0.01 & 0.23 & 0.001 \\
\hline
\end{tabular}

Table (3): Slaughter parameters of Japanese quails as affected by treatment and sex at 38 days of age (Main effects).

\begin{tabular}{|c|c|c|c|c|c|c|}
\hline Item & Edible parts (g) & Dressing \% & $\begin{array}{l}\text { Dressed meat } \\
(\mathrm{g})\end{array}$ & Meat $\%$ & Giblets (g) & Giblets $\%$ \\
\hline \multicolumn{7}{|l|}{ Treatment effect: } \\
\hline Control & 155.89 & 75.45 & 79.65 & 38.54 & 12.74 & 6.20 \\
\hline Grape seeds $1 \%$ & 162.93 & 73.82 & 82.97 & 37.63 & 12.65 & 5.67 \\
\hline Grape seeds $3 \%$ & 155.23 & 71.50 & 76.37 & 34.99 & 12.67 & 5.76 \\
\hline SEM $^{1}$ & 6.13 & 2.53 & 3.93 & 1.51 & 0.92 & 0.37 \\
\hline P-value & 0.63 & 0.56 & 0.51 & 0.27 & 0.99 & 0.57 \\
\hline \multicolumn{7}{|l|}{ Sex effect: } \\
\hline Females & $167.81^{\mathrm{a}}$ & 73.03 & 84.44 & 36.67 & 14.39 & 6.25 \\
\hline Males & $148.23^{b}$ & 74.14 & 74.88 & 37.43 & 10.98 & 5.50 \\
\hline SEM & 5.00 & 2.07 & 3.21 & 1.24 & 0.75 & 0.30 \\
\hline $\mathrm{P}$-value & 0.02 & 0.71 & 0.10 & 0.67 & 0.01 & 0.10 \\
\hline
\end{tabular}

\footnotetext{
${ }^{a-b}$ Means within the same column with different superscript; $\quad$ SEM ${ }^{1}$ : Pooled standard error

Edible parts $(g)=$ giblets weight $(g)+$ carcass weight $(g)$

Dressing $\%=\left(\right.$ edible parts $\left.(g) / L B W_{38}(g)\right) \times 100 ; \quad$ Dressed meat $(g)=$ boneless meat $(g)$

Meat $\%=\left(\right.$ dressed meat $\left.(g) / L B W_{38}(g)\right) \times 100$
} 
Results presented in Table 4 revealed that neither treatment nor sex significantly influenced all carcass chemical composition of quail meat, except ash\%. Carcass of quail fed diet supplemented with GS $1 \%$ had the highest ash\% whereas the GS 3\% group had the lowest ash\% $(P \leq 0.01)$. These results are in agreement with the reports of Abu Hafsa and Ibrahim (2017) who reported that the physical characteristics of meat and the chemical composition of DM, CP and ash were not significantly influenced by dietary inclusion of graded concentrations of GP in broiler diet.

Treatment effect significantly influenced all serum biochemical indices at slaughter studied as shown in Table 5. Groups fed GS had lower total Chol than the control group. Quail fed the GS 1\% diet had desirably the highest HDL moreover, the GS 3\% group had lower $(\mathrm{P}>0.05)$ estimates of LDL, VLDL, Trig, RBS, AST and ALT than the control group. In other words, supplementing diets with graded level of GS from 1 up to 3\% decreased total Chol, lipid profile, RBS and liver enzyme activities (Table 5).

Table (4). Chemical composition of Japanese quail meat \% as affected by treatment and sex (Main effects).

\begin{tabular}{lccccc}
\hline Item & Moisture & Crude Protein & Fat & Ash & NFE \\
\hline Treatment effect: & & & & & \\
Control & 66.60 & 20.60 & 9.41 & $2.00^{\mathrm{b}}$ & 1.38 \\
Grape seeds 1\% & 66.28 & 20.77 & 9.32 & $2.23^{\mathrm{a}}$ & 1.40 \\
Grape seeds 3\% & 66.44 & 20.72 & 9.41 & $1.96^{\mathrm{b}}$ & 1.47 \\
SEM $^{1}$ & 0.20 & 0.18 & 0.12 & 0.06 & 0.04 \\
P-value & 0.54 & 0.80 & 0.84 & 0.01 & 0.35 \\
Sex effect: & & & & & \\
Females & 66.37 & 20.67 & 9.46 & 2.05 & 1.45 \\
Males & 66.51 & 20.72 & 9.31 & 2.08 & 1.38 \\
SEM & 0.17 & 0.15 & 0.10 & 0.05 & 0.04 \\
P-value & 0.54 & 0.82 & 0.29 & 0.67 & 0.16 \\
\hline SEM ${ }^{1}$ Poted stan
\end{tabular}

SEM ${ }^{1}$ : Pooled standard error

${ }^{a-b}$ Means within the same column with different superscript

Table (5): Serum biochemical indices at slaughter as affected by treatment and sex (Main effects).

\begin{tabular}{|c|c|c|c|c|c|c|c|c|}
\hline Item & $\begin{array}{c}\text { Total Chol } \\
(\mathrm{mg} / \mathrm{dl})\end{array}$ & $\begin{array}{c}\text { HDL } \\
(\mathrm{mg} / \mathrm{dl})\end{array}$ & LDL (mg/dl) & $\begin{array}{c}\text { VLDL } \\
(\mathrm{mg} / \mathrm{dl})\end{array}$ & $\begin{array}{c}\text { RBS } \\
(\mathrm{mg} / \mathrm{dl})\end{array}$ & $\begin{array}{c}\text { Trig } \\
(\mathrm{mg} / \mathrm{dl})\end{array}$ & $\begin{array}{c}\text { AST } \\
(\mathrm{U} / \mathrm{L})\end{array}$ & $\begin{array}{c}\text { ALT } \\
(\mathrm{U} / \mathrm{L})\end{array}$ \\
\hline \multicolumn{9}{|l|}{ Treatment effect: } \\
\hline Control & $189.64^{\mathrm{a}}$ & $104.13^{\mathrm{a}}$ & $67.51^{\mathrm{a}}$ & $18.01^{\mathrm{a}}$ & $235.68^{a}$ & $124.79^{\mathrm{a}}$ & $99.12^{\mathrm{a}}$ & $17.33^{\mathrm{a}}$ \\
\hline Grape seeds $1 \%$ & $159.71^{b}$ & $104.91^{\mathrm{a}}$ & $38.44^{b}$ & $16.35^{\mathrm{ab}}$ & $161.01^{b}$ & $104.62^{b}$ & $95.32^{\mathrm{a}}$ & $16.57^{b}$ \\
\hline Grape seeds $3 \%$ & $133.67^{\mathrm{c}}$ & $86.95^{b}$ & $33.49^{b}$ & $13.22^{b}$ & $152.45^{\mathrm{c}}$ & $103.74^{b}$ & $79.15^{b}$ & $12.89^{b}$ \\
\hline SEM $^{1}$ & 4.13 & 2.51 & 2.25 & 1.31 & 2.10 & 2.69 & 1.53 & 1.02 \\
\hline $\mathrm{P}$-value & 0.001 & 0.004 & 0.001 & 0.066 & 0.001 & 0.002 & 0.001 & 0.02 \\
\hline \multicolumn{9}{|l|}{ Sex effect: } \\
\hline Females & $168.25^{\mathrm{a}}$ & $102.11^{\mathrm{a}}$ & $50.25^{\mathrm{a}}$ & 15.90 & $179.21^{b}$ & $115.20^{\mathrm{a}}$ & $88.18^{b}$ & $12.66^{\mathrm{b}}$ \\
\hline Males & $153.76^{b}$ & $95.22^{\mathrm{b}}$ & $42.71^{\mathrm{b}}$ & 15.82 & $186.88^{a}$ & $106.90^{\mathrm{b}}$ & $94.21^{\mathrm{a}}$ & $18.53^{\mathrm{a}}$ \\
\hline SEM & 3.37 & 2.05 & 1.84 & 1.07 & 1.72 & 2.19 & 1.25 & 0.84 \\
\hline $\mathrm{P}$-value & 0.01 & 0.035 & 0.01 & 0.96 & 0.01 & 0.02 & 0.005 & 0.01 \\
\hline
\end{tabular}

Chol: Cholesterol, HDL: High density lipoprotein, LDL: Low density lipoprotein, VLDL: Very low density lipoprotein, RBS: Random blood Sugar, Trig: Triglycerides, AST: Aspartate aminotransferase, ALT: Alanine aminotransferase.

${ }^{a \ldots . . c:}$ Means within the same column with different superscript. SEM ${ }^{l}$ : Pooled standard error. 
Similarly, sex significantly affected all serum biochemical indices at slaughter, except VLDL (Table 6). Females had higher total Chol, HDL, LDL and Trig than males however males exceeded females in RBS and liver enzymes (AST and ALT). The present results on blood parameters were found to be within normal ranges in healthy chicks and are in agreement with those obtained by Fawzia et al. (2014) and Abu Hafsa and Ibrahim (2017) who reported lower plasma glucose and total lipid levels of rabbits fed a GSP diet than the control group. The high concentration of antioxidants might decrease the serum concentration of triglycerides (Akbari and Torki, 2014). However, Ozcan et al. (2009) proposed that the dietary inclusion of $2 \%$ GS oil significantly increased plasma glucose while decreasing plasma cholesterol concentrations in mice. The present finings confirmed those reported by Fawzia et al. (2014) and Abu Hafsa and Ibrahim (2017) they found that grape seed supplementation in the diet significantly affected blood plasma AST and ALT levels of broilers, which, agreed with who found that the blood plasma GOT level of growing rabbits fed the control diet was significantly higher relative to that of rabbits fed GSP $0.5 \%, 1.0 \%$ and $1.5 \%$ diets. In contrast, Chamorro et al. (2013) found that plasma cholesterol and triglyceride concentrations were not affected by dietary GS extract. Grape seed supplementation in the diet did not significantly affect blood plasma AST and ALT levels of broilers. Similarly, Ebrahimzadeh et al. (2018) GP supplementation to chicken diets did not have any significant impact on serum glucose while decreased triglycerides, LDL and increased HDL concentration of serum blood of broilers. In this study, the hypolipidemic effects of GP might not originate from their direct effect on lipid metabolism; however, it could be mediated by their effect on lowering oxidized lipid products. This effect may be associated with an increase in the plasma HDL concentration of the respective treatment groups (Ebrahimzadeh et al., 2018). Either antioxidant parameters (GPx and TBAR) or immune responses significantly $(P \leq 0.001)$ affected by treatment effect (Table 6$)$.

Table (6): Antioxidant parameters and immune response as affected by different dietary treatments and sex (Main effects).

\begin{tabular}{|c|c|c|c|c|c|}
\hline \multirow{2}{*}{$\frac{\text { Item }}{\text { Treatment effect: }}$} & \multicolumn{2}{|c|}{ Antioxidant parameters } & \multicolumn{3}{|c|}{ Immune response } \\
\hline & & & & & \\
\hline & $\begin{array}{c}\text { GPX } \\
(\mathrm{nmol} / \mathrm{min} / \mathrm{ml})\end{array}$ & TBAR (nmol /ml) & $\operatorname{IgG}(\mathrm{mg} / \mathrm{dl})$ & $\operatorname{IgA}(\mathrm{mg} / \mathrm{dl})$ & $\operatorname{IgM}(\mathrm{mg} / \mathrm{dl})$ \\
\hline Control & $6.43^{c}$ & $1.86^{\mathrm{a}}$ & $936.15^{\mathrm{b}}$ & $175.53^{\mathrm{b}}$ & $93.62^{b}$ \\
\hline Grape seeds $1 \%$ & $6.96^{\mathrm{b}}$ & $1.49^{\mathrm{b}}$ & $1091.12^{\mathrm{a}}$ & $204.58^{\mathrm{a}}$ & $109.11^{\mathrm{a}}$ \\
\hline Grape seeds $3 \%$ & $8.92^{\mathrm{a}}$ & $1.10^{\mathrm{c}}$ & $1129.00^{\mathrm{a}}$ & $211.69^{\mathrm{a}}$ & $112.90^{\mathrm{a}}$ \\
\hline SEM $^{1}$ & 0.13 & 0.06 & 22.29 & 4.18 & 2.23 \\
\hline P-value & 0.001 & 0.001 & 0.001 & 0.001 & 0.001 \\
\hline Sex effect: & & & & & \\
\hline Females & 7.68 & 1.46 & 1051.20 & 188.07 & 105.12 \\
\hline Males & 7.86 & 1.51 & 1052.98 & 187.41 & 105.30 \\
\hline SEM & 0.10 & 0.05 & 18.20 & 3.41 & 1.82 \\
\hline P-value & 0.23 & 0.42 & 0.95 & 0.95 & 0.95 \\
\hline
\end{tabular}

The inclusion of GS in quail diets increased GPx, immune responses (IgG, $\operatorname{IgA}$ and $\operatorname{IgM})$ and decreased TBAR as compared to the unsupplemented diet (control group) the treatment effect was in favor the GS 3\% group. The GPx level was observed to move up constantly with increasing dietary levels of GS. On the contrary, sex effect did not influence all antioxidant parameters and immune responses as shown in Table 6. Grape pomace pomace can be a new source of antioxidants for animal nutrition and also a potential antioxidant. Martel et al. (2010) reported that there are many different factors including the type of compounds, its dosage and combination with other compounds effecting on absorption and assimilation of different nutrients for polyphenolic compounds. The discrepancy in reaction consequent on adding GSE in different experiences could be attributed to the difference in concentration and type of polyphenols and proanthocyanidins in the examined products. High level of polyphenols could interact with proteins (of either dietary or endogenous origin including digestive 
enzymes) and form tannin-protein complexes that decrease efficiency of nutrient utilization and depress growth performance (Jansman et al., 1994 and Brenes et al., 2008). The present study confirmed that polyphenols present in GS were absorbed at sufficient levels to contribute to, and modulate, the antioxidant activity in quail (Goñi et al., 2007; Brenes et al., 2008; Fawzia et al., 2014; Abu Hafsa and Ibrahim, 2017 for chickens) and Hajati et al. (2015). Grape by-products show their antioxidant characteristics through the attribute of the phenolic compounds to scavenge free radicals by forming complexes with metal ions and preventing the development of singlet oxygen (Surai, 2014). The level of TBARS was significantly reduced when the inclusion rate of GS was increased. The reduced levels of lipid peroxides following supplementation with GSs may have been associated with increased antioxidant enzyme activity and GPx content. GSs were found to be rich in flavonoids, which have antioxidant properties. This means that the GS could reduce reactive free radicals and thereby reduce oxidative damage to tissues. The present study are in agreement with the findings of Fawzia et al. (2014) found that the blood plasma GPx level of rabbits fed higher GSP (1.5\%) diet was significantly higher relative to those fed lower levels and the control diets. These results indicated that grape polyphenols and flavonoids fraction are active compounds that act as effective antioxidants and increase the resistance of plasma against oxidative stress through the activation of the antioxidant enzyme system (Abu Hafsa and Ibrahim, 2017). In poultry production, it is more effective to use immune stimulators to improve immunity and decrease susceptibility to infectious disease. Evidence from various studies suggests that the mechanisms on how the plant polyphenols exert their properties, such as inhibition of key enzymes, the modulation of cell receptors or transcription factors, as well as the perturbation of protein aggregates, which can regulate cell functions related to, or example, growth and proliferation, inflammation, apoptosis, angiogenesis, metastasis, and immune responses, in various ways by affecting signal transduction pathways (Yang et al., 2009). Similarly, Iqbal et al. (2015) found that replacement of $75 \mathrm{ppm}$ vitamin $\mathrm{E}$ with grape polyphenols showed higher $(\mathrm{P}<0.05)$ antibody titers against NDV in broilers. Additionally, Acamovic and Brooker (2005) reported that polyphenols and oregano essential oil have an immuno-stimulating activity in relation to the system of mononuclear phagocyte system, cell, and humoral immunity.

In the current study, GS caused significant growth-promoting effects, reduced the populations of intestinal E. coli and Salmonella and increased the intestinal beneficial Lactobacilli bacteria (Table 7).

Table (7): Useful and harmful intestinal bacteria in growing quails as affected by different dietary treatments and sex (Main effects).

\begin{tabular}{lccc}
\hline Item & $\begin{array}{c}\text { Lactobacillus spp (log 10 cfug) } \\
\text { Treatment effect: }\end{array}$ & & $\begin{array}{c}\text { Salmonella }(\log 10 \\
\text { cfug) }\end{array}$ \\
Control & $6.52^{\mathrm{b}}$ & $8.40^{\mathrm{a}}$ cfug) & $8.22^{\mathrm{a}}$ \\
Grape seeds1\% & $7.37^{\mathrm{a}}$ & $7.75^{\mathrm{b}}$ & $7.36^{\mathrm{b}}$ \\
Grape seeds3\% $^{\mathrm{a}} \%$ & $7.01^{\mathrm{c}}$ & $6.85^{\mathrm{b}}$ \\
SEM $^{1}$ & $7.35^{\mathrm{a}}$ & 0.21 & 0.24 \\
P-value & 0.22 & 0.002 & 0.006 \\
Sex effect: & 0.029 & & 7.51 \\
Females & & 7.83 & 7.44 \\
Males & 7.23 & 7.61 & 0.20 \\
SEM & 6.94 & 0.17 & 0.797 \\
P-value & 0.18 & 0.378 &
\end{tabular}

cfug: logarithm of colony forming unit per gram of digesta

a...: Means within the same column with different superscript

Polyphenols could have bacteriostatic or bactericidal action or could act to inhibit the adhesion of infection-causing bacteria within cells of the intestinal tract (Viveros et al., 2011) as the $\mathrm{pH}$ in the gastrointestinal tract may have been lowered due to the active components of herbal derivatives. They reported that some micro-organisms were able to use these compounds as nutritional substrates. In the 
particular case of Lactobacilli, these bacteria had the ability to metabolize phenolic compounds supplying energy to cells and positively affect bacterial metabolism (García-Ruíz et al., 2008). Thus, the active components of herbal derivatives could help to prevent the growth of pathogenic bacteria and promote the population of nonpathogenic ones such as Lactobacillus spp. (Khaksar et al., 2012). The present results partially in agreement with those of Hajati et al. (2015) who reported that dietary GS decreased the ileal population of E. coli. However, there were no significant differences between populations of lactobacillus.

\section{REFERENCES}

Acamovic, T. and J.D. Brooker (2005). Biochemistry of plant secondary metabolites and their effects in animals. Proc. Nutr. Soc. 64: 403-412.

Akbari, M and M. Torki (2014). Effects of dietary chromium picolinate and peppermint essential oil on growth performance and blood biochemical parameters of broiler chicks reared under heat stress conditions. Inter. J. of Biometeorology, 58: 1383-1391.

AOAC (2005). Official methods of analysis 16th Ed. Association of official analytical chemists. Washington DC, USA.

Bişboacă, S. E. (2012). A process to obtain the polyphenols from grape pomace . Romanian State Office for Inventions and Trademarks. Patent RO 125704 B1. 2012. pp.1-5.

Brenes, A., A. Viveros, C. Saura and I. Arija (2016). Use of Polyphenol-rich grape by-products in monogastric nutrition.Anim. Feed Sci. Technol. 1:1-17.

Brenes, A., A.Viveros, I. Goni, C. Centeno, S.G. Sayago-Ayerdi, I. Arija and F. Saura-Calixto (2008). Effect of grape pomace concentrate and vitamin E on digestibility of polyphenols and antioxidant activity in chickens. Poul. Sci. 87, 307-316.

Brody, S. 1945)._Bioenergetics and Growth. New York: Reinhold Publishing Co.

Carpenter, R., M. N., O’Grady, Y. C. O’Callaghan, N. M. O’Brien and J. P. Kerry, (2007). Evaluation of the antioxidant potential of grape seed and bearberry extracts in raw and cooked pork. Meat Sci. 76: 604-610.

Chamorro, S., A. Viveros, C. Centeno, C. Romero, I. Arija nd A. Brene0 (2013). Effects of dietary grape seed extract on growth performance, amino acid digestibility and plasma lipids and mineral content in broiler chicks. Animal, 7, 555-561.

Duncan, D. B. (1955). The multiple ranges and multiple F Test. Biometrics.11: 1-42.

Ebrahimzadeh, S. K., B. Navidshad, P. Farhoomand And F. Mirzaei Aghjehgheshlagh (2018). Effects of grape pomace and vitamin $\mathrm{E}$ on performance, antioxidant status, immune response, gut morphology and histopathological responses in broiler chickens. South African Journal of Animal Science 2018, 48 (No. 2).

Erhard, M. H., I. Von Quistorp, I. Schranner, A. Jüngling, B. Kaspers, P. Schmidt, and R. Kühlmann (1992). Development of specific enzyme-linked immunosorbent antibody assay systems for the detection of chicken immunoglobulins G, M, and A Using Monoclonal Antibodies. Poultry Science, Volume 71, Issue 2, 1 February 1992, Pages 302-310.

FAOSTAT (2018). FAOSTAT - Food and Agriculture Organization of the United Nations. Retrieved from http://faostat3.fao.org/faostat-gateway/go/to/ download/Q/QC/E.

Fawzia, A. H., M. Khalid and M. M. Basyony (2014). Influence of grape seeds powder as a natural Antioxidant on growth performance, antioxidant Status and carcass characteristics of rabbits under hot conditions. Proceedings of the 7th International Conference on Rabbit Production in Hot Climate, 8-12 September, 2014, Marsa Alam, Egypt, pp. 395-412.

Furiga, A., A. Lonvaud-Funel and C. Badet, (2008). In vitro study of antioxidant capacity and antibacterial activity on oral an-aerobes of a grape seed extract. Food Chemistry, 113: 1037-1040. 
García-Ruíz, A., B. Bartolomé, A. J. Martínez-Rodríguez, E. Puello, P. J. MartínÁlvarez and M. V. Moreno-Arribas (2008). Potential of phenolic compounds for controlling lactic acid bacteria growth in wine. Food Control J., 19:_835-841.

Goni , I., A. Brenes, C. Centeno, A. Viveros, A. Saura-Calixto, I. Rebole and R. Arija, (2007). Effect of dietary grape pomace and vitamin $\mathrm{E}$ on growth performance, nutrient digestibility and susceptibility to meat lipid oxidation in chickens. Poult. Sci., 86: 508-516.

Gorinstein, S., M. Zemser, M. Weisz, S. Halevy, J.Deutsch, Tilus, K. and E. Bartnikowska, (1994). Fluorometric analysis of phenolics in persimmons. Bioscience, Biotechnology and Biochemistry, 58: $1087-1092$.

Hajati, H., A. Hassanabadi, A. Golian, H. Nassiri-Moghaddam and M.R. Nassiri, (2015). The effect of grape seed extract and vitamin $\mathrm{C}$ feed supplementation on some blood parameters and HSP70 gene expression of broiler chickens suffering from chronic heat stress. Itali. J. Anim. Sci., 14: 3273.

Hughes, R.J., J.D. Brooker and C. Smyl (2005). Growth rate of broiler chickens given condensed tannins extracted from grape seed. Proceedings of the $17^{\text {th }}$ Australian Poultry Science Symposium, 7-9 February 2005, Sydney, NSW, Australia, pp. 65-68.

Iqbal, Z., Z. Kamran, J. I.Sultan, A. Ali, S.Ahmad, M. I. Shahzad, U. Ahsan, S. Ashraf and M. U. Sohail (2015). Replacement effect of vitamin E with grape polyphenols on antioxidant status, immune, and organs histopathological responses in broilers from 1 to 35-d age. J. Appl. Poult. Res., 24:127-134

Ismail, A. M., A. A. Sedki and A. G. Abdallah (2003). Influence of black seed, garlic and onion supplementation on reproductive performance and immune functions in rabbits. Egyp. J. Agric. Res., 81: 1193-1207

Jansman, A.J.M., A.A. Frohlich and R.R. Marquardt (1994). Production of proline-rich proteins by the parotid glands of rats is enhanced by feeding diets containing tannins from faba beans (vicia faba L). J. of Nutr.. 124: 249-258.

Kermauner, A. and A. Laurenčič (2008). Supplementation of rabbit diet with chestnut wood extract. Effect on invitro gas production from two sources of protein. In: Proceedings of the 9th World Rabbit Congress, Verona, June10-13, 2008, pp.689-693.

Khaksar, V., A. Golian and H. Kermanshahi (2012). Immune response and ileal microflora in broilers fed wheat-based diet with or without enzyme Endo feed $\mathrm{W}$ and supplementation of thyme essential oil or probiotic PrimaLac®. African J. of Biotechnology, 11: 14716-14723.

Lichovnikova, M., L. Kalhotka, V. Adam, B . Klejdus and V.Anderle (2015). The effects of red grape pomace inclusion in grower diet on amino acid digestibility, intestinal microflora, and sera and liver antioxidant activity in broilers. Turkish J. of Vet. and Anim. Sci., 39: 406-412.

Martel, F., R. Monteiro and C. Calhau (2010). Effect of polyphenols on the intestinal and placental transport of some bioactive compounds. Nutr. Res. Reviews: 23:47-64.

Nardoia, M. (2016). Effect of dietary polyphenol-rich grape by-products on growth performance, some physiological parameters, meat and meat products quality in chickens, $\mathrm{PhD}$ thesis. Institute of Food Science Technology and Nutrition, the Spanish Science Research Council (CSIC), Madrid, Spain.

National Research Council, NRC, 1994. Nutrient Requirements of Poultry. 9th revised edition. National Academy Press. Washington, D.C., USA.

North, M.O. (1981).Commercial Chicken Production Manual, $2^{\text {nd }}$ Edition. AVI Publishing Company Inc, USA.

Ozcan, A., L. Celik, H. R. Kutlu, Z. Sahan, U. Serbester, A. Tekeli and A. B. Kiraz (2009). Dietary use of Grape seed oil in functional egg production. Proceedings of the national Animal Nutrition Congress (International Participation), 30 September-03 October 2009. Çorlu, Tekirdað, Turkey, pp. 139-143.

Paglia, D.E. and W.N.Valentine (1967). Studies on the quantitative and qualitative characterization of erythrocyte glutathione peroxidase. J. of Laboratory and Clinical Medicine 70: 158-169. 
Pascariu, S.M., I.M. Pop, D. Simeanu , G. Pavel and C. Solcan (2017). Effects of wine by-Products on growth performance, complete blood count and total antioxidant status in broilers. Brazilian J. of Poul. Sci., ISSN 1516-635X Apr - Jun 2017 / v.19 / n.2 / 191-202.

Perumalla, A. V. S and N. S. Hettiarachchy (2011). Green tea and grape seed extracts-potential applications in food safety and quality. Food Res. Inter., 44: 827-839.

Rebaya, A., S.I. Belghith, B. Baghdikian, V.M. Leddet, F. Mabrouki, E.Olivier (2015). Total phenolic, totalflavonoid, tannin content, andantioxidant capacity of Halimium halimifolium (Cistaceae). J Appl Pharm Sci2015;5: 52-7.

Satyam, S. M., L. K. Bairy, R. Pirasanthan and R. L. Vaihnav (2013). Grape seed extract and zinc containing nutritional food supplement decreases the oxidative stress induced by carbon tetrachloride in rats. Inter. J. of Pharmacology and Pharmaceutical Sci, 5: 626-631.

SPSS (2013). IBM SPSS Statistics for Windows, Version 22.0. Armonk, NY: IBM Corp. Released 20 13.

Surai, P.F. (2014). Polyphenol compounds in the chicken/animal diet: from the past to the future. J. Anim. Physiol. Anim .Nutr. 98:19-31.

Tepe, B., D. Daferera, M. Sokmen, M. Polission and A. Sokmen (2004). In vitro antimicrobial and antioxidants activities of essential oils and various extracts of Thymus eigii. J. Agri. Food Chem. 52: 1132-1137.

Viveros, A., S. Chamorro, M. Pizarro, I. Arija, C. Centeno and A. Brenes (2011). Effects of dietary polyphenol-rich grape products on intestinal microflora and gut morphology in broiler chicks. Poult. Sci., 90: 566-578.

Yagi, K. (1998). Simple assay for the level of total lipid peroxides in serum or plasma. Methods in Molecular Biology 108: 101-106.

Yang, C.S., X. Wang, G. Lu, and S.C., Picinich (2009). Cancer antioxidant redox signaling. Life Sci. 7: 1704-1714. 
تأثير اضـافة بذور العنب للعليقهـ كمنشط نمـو طبيعي على الأداء الإنتاجي ومكونـات اللـم ومضـادات الاكسـده وميكروفلورا الامعاء للسمان الياباني النامي لبني

\author{
عبد الوهاب عبد الله عبد الوهاب1 ; ابراهيم عبد التواب عبد القادر1 و ايناس احمد محم²

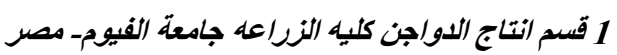

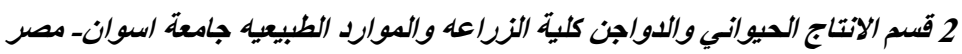

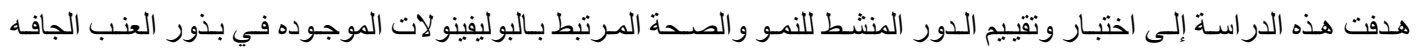

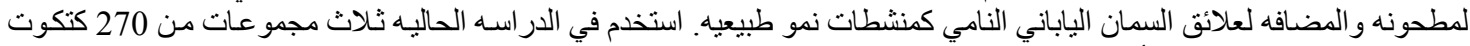

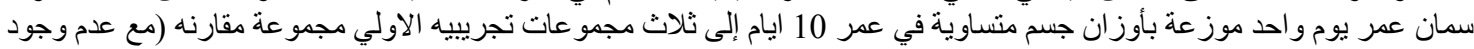

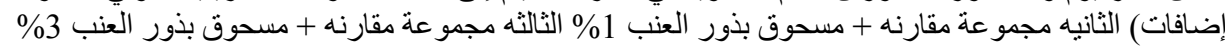
لفحص تأثثر اضـافه بذور العنب على أداء النمو، وخصـائص الذبيحة، ومكونـات الدم، ومضـادات الأكسدة في الدم، والاستجابة المناعيـة، و الميكروفلورا المعوية في السمان الياباني. أظهرت أهم النتائج ما يلي:

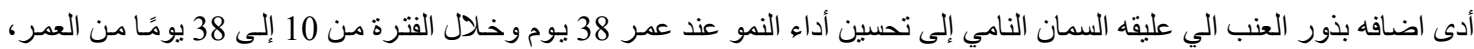

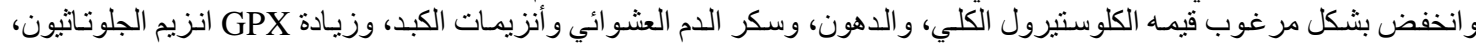

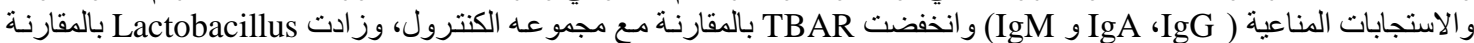

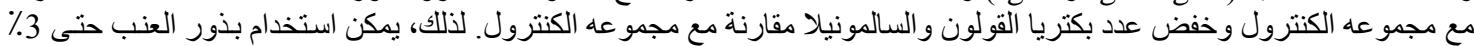
كمحفز للنمو دون الإضر النير بنمو السمان. 